\title{
The Interaction Effect of Learning Methods and Naturalist Intelligence Toward Children's Art Creativity
}

\author{
Anita Damayanti ${ }^{1}$, Makruf Akbar ${ }^{2}$ and Yufiarti ${ }^{3}$ \\ \{anita.dama9@gmail.com ${ }^{1}$, maruf.akbar@unj.ac.id², yufiarti@unj.ac.id ${ }^{3}$ \} \\ Universitas Negeri Jakarta, Indonesia ${ }^{1,2,3}$
}

\begin{abstract}
This study aims to look at the interaction Effect of learning methods and naturalist intelligence on the artistic creativity of first grade elementary school students, West Java province, Indonesia. The research method used experimental treatment with the level 2 x 2 method. The results showed that the learning method used by the teacher in the learning process and naturalist intelligence possessed by students had a significant effect of interaction on artistic creativity. The results of the two-way variance calculation at a significant level $\alpha=0.05$ that the price of $\mathrm{F}$ count interaction $=54.141$ and $\mathrm{F}$ table $(0.01 ; 1.96)=6.91$. The conclusion of this study is that there is an effect of the interaction between learning methods and naturalist intelligence on students' artistic creativity.
\end{abstract}

Keywords: Learning Methods, Naturalist Intelligence, Art Creativity.

\section{Introduction}

Creativity comes from the word 'creative' which means the ability to create. This ability can be built or developed through the activity of playing art and science. The importance of art education in schools, especially two-dimensional art such as pictures or paintings can develop children's thinking creativity. Art activities are effective stimulation to develop children's imagination, thinking creativity, and expression [1], enhance conceptual abilities [2], learn to respect works and offer opportunities to solve problems[3], teach children to be patient and independent[4], giving freedom to explore materials[5], to be manipulated into a new form [6] and [7] and improve motoric skills [8].

The importance of utilizing the surrounding natural environment as a source of learning the art for children is so that children learn to elaborate and use simple analytical skills to recognize objects [9]. Children are trained to observe objects carefully, paying attention to each unique part both in shape, size, type and color. Learning by utilizing the surrounding natural environment [10], children get learning habits that are independent, easy and interesting so that children are expected to be aware that learning is not only in the classroom, but a surrounding environment is also a place for learning [11]. Interactions between the ability and intelligence of the process and the environment can develop children's creativity [12]. Besides, the use of natural elements brings positive effects in facilitating children to create creative works [13]. This can develop children's naturalist intelligence [14]. Children who have high naturalist intelligence have a concern for the environment and are able to associate natural components with each other [15], love collecting plant parts to be used to 
make ornaments or crafts [16], are able to distinguish flora, fauna and recognize patterns and colors [17]. Thus students who have high naturalist intelligence will enjoy exploring natural materials that exist in the surrounding environment and are able to use them to make a beautiful work of art.

The opportunity to develop thinking creativity through the creation of fine art works in first grade elementary school students is obtained through art and culture lessons that are supported by the right learning methods. The learning method is a procedure that is arranged regularly in an activity plan to achieve learning goals [18] and [19]. Drill methods and demonstration methods are learning methods that can be used to achieve the goal of art learning for first grade students in elementary school, including enhancing students' thinking creativity through playing two-dimensional art activities, namely making pictures or paintings using materials from nature.

The drill learning method is a method of repetitive training that will provide experience. Students will look for the best way of doing movements. The experience of learning art through exercises to produce images of various natural materials that have been obtained by students will enrich ideas to produce creative designs in different or new forms [20] and [21]. Through agility, skills, and the ability to use tools, finishing drawings becomes faster [20] and [22]. In addition, the drill method can also improve long-term memory skills [23] and eye and hand coordination skills so that cognitive non-art learning transfer occurs [6].

Demonstration method is a way of presenting lessons to demonstrate a process [24] based on hearing and vision results [25], then students do what the teacher exemplifies correctly and in detail [26] and [11] The example done by the teacher creates a creative space that encourages the development of students' creativity [27].

Based on theoretical studies and the results of the research described, it is shown that there is a very significant effect of interaction between learning methods and naturalist intelligence on artistic creativity. The use of drill learning method stimulates students to be more creative in making fine art works for students who have high naturalist intelligence, because they gain more experience through exercises that are given actively so students are free to explore materials from their preferred nature through the sharpness of their senses conforming their imagination to create [9]. Teacher-centered demonstration learning method with work orientation that must be the same as what the teacher demonstrates is more suitable for students who have low naturalist intelligence, because students lack interest in exploring the environment and natural materials to do works. Students prefer to use materials that already exist and follow the example that the teacher made, refusing to look for or try other forms that are different.

\section{Methods}

The method of this research is experimentation, treatment design by level $2 \times 2$ with twoway analysis of Anava with the aim to determine whether there is an influence of interaction between learning methods and naturalist intelligence on the creativity of fine arts of first grade students in elementary school. The subjects of this research were 100 first grade students of Bekasi Regency, West Java Province, Indonesia. The data used is quantitative data. Statistical data analysis uses a two-way analysis of variance (Anava) with the $\mathrm{F}$ test at the 0.05 significance level 


\section{Discussion}

The use of drill learning methods can stimulate students to be more creative in making two-dimensional works of art, especially for students who have high naturalist intelligence, because in this method students are given more opportunities to gain experience through actively given training to freely explore materials material from nature that he likes through the sharpness of his senses according to his imagination to work [9]. Repetitive exercises carried out by students in this drilling method, students are given the freedom to use different materials even though the techniques used are the same. The freedom to use different materials will produce works that are different from what was made in the previous exercise, this will provide students with experience of the various forms of images they produce and enrich ideas to produce creative designs in different forms [20] [21] or integrating several existing ones into other different forms [8]. In addition, the use of the same techniques over and over again makes students more flexible and skilled in using the tools so that the completion time can make his work faster.

Conversely, students who have low naturalist intelligence, they do not like the drill method in art lessons, because they do not like natural objects or anything related to nature. Students with low naturalist intelligence preferred to study art with demonstration methods, because in this method students only modeled what the teacher had made [26] with the same material, no need to think hard to make the work assigned to him. Students who have low intelligence lack interest in exploring the environment and materials from nature to make works, they prefer to use available materials and create works similar to those demonstrated by the teacher.

\section{Result}

Based on the results of two-way analysis of variance about the effect of the interaction between learning methods and naturalist intelligence on the scores of students' artistic creativity, see the table below:

Table 1. Test of Betwen-Subjects Effects

\begin{tabular}{l}
\multicolumn{7}{c|}{ Dependen Variable: Art Creativity } \\
\begin{tabular}{|l|r|r|r|r|r|}
\hline Source & $\begin{array}{c}\text { Type III Sum } \\
\text { of Squares }\end{array}$ & df & Mean Square & \multicolumn{1}{c|}{ F } & Sig. \\
\hline Corrected Model & $706,000($ a) & 3 & 235,333 & 22,128 &, 000 \\
Intercept & 92903,040 & 1 & 92903,040 & 8735,594 &, 000 \\
A & 81,000 & 1 & 81,000 & 7,606 &, 007 \\
B & 49,000 & 1 & 49,000 & 4,607 &, 034 \\
A * B & 576,000 & 1 & 576,000 & 54,141 &, 000 \\
Error & 1020,960 & 96 & 10,635 & & \\
Total & 94630,000 & 100 & & & \\
Corrected Total & 1726,960 & 99 & & & \\
\hline
\end{tabular} \\
a R Squared $=, 409$ (Adjusted R Squared $=, 390)$ \\
\hline
\end{tabular}

It can be seen in the table of two-way Anava calculation above, that the price of $\mathrm{F}$ calculated interaction $=54.141$ and Ftable $(0.01 ; 1: 96)=6.91$. Based on the value of Sig. in the Tests of Between-Subjects Effects table for line A* B with provisions if it is less than 0.05 then the 
test results are significant or $\mathrm{H} 0$ is rejected. In Table 1, it can be seen that the value of Sig. for row $\mathrm{A} * \mathrm{~B}$ is 0,000 ; less than 0.05 then $\mathrm{H} 0$ is rejected so $\mathrm{H} 1$ is accepted. The conclusion is that there is an interaction between learning methods and naturalist intelligence on student visual creativity. The interaction between learning methods and naturalist intelligence on student visual creativity can be seen in the following figure.

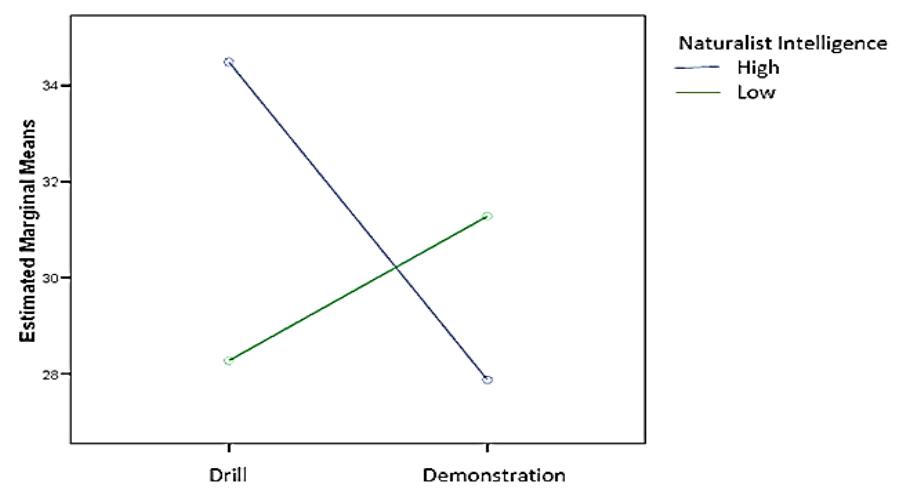

Figure 1. Estimated Marginal of Art Creativity

The results of the two-way variance analysis in the $\mathrm{A} * \mathrm{~B}$ Interaction line found that the $\mathrm{F}$ count interaction was 54.141 greater Ftable $(0.01 ; 1: 96)=6.91$ with a probability value (Sig.) Of 0,000 smaller than the significant level $(0,05)$. This means that there is a very significant interaction effect between learning methods and naturalist intelligence on student visual creativity.We hope you find the information in this template useful in the preparation of your submission.

\section{Conclusions}

The conclusion of this study is that there is a very significant interaction effect between learning methods and naturalist intelligence on artistic creativity. And thus can be concluded that, the learning method factor for artistic creativity depends on the level of naturalist intelligence that the child has.

\section{References}

[1] Margaret S. Barret, Michele C. Everett, Heather M. Smigiel 'Meaning, Value and Engagement in Art: Findings from a Participatory Investigation of Young Australian Children's Perception of the Art,' Springer Science+Business Media B.V (2012).

[2] Anna Craft. 'Creative Thinking in Early Years of Education,' J. Early Years., vol. 23 issue 2 (2010).

[3] Shedd, Meagan K, Coyner, Rebecca L. 'Every Color on the Canvas,' J. YC: Young Children (2015).

[4] Reilly, Kathleen. 'Art in Early Childhood: Using a Project Approach,'J. Educating Young Children: Learning and Teaching in the Early Childhood Years (2014).

[5] M. Susan McWilliams, Ashley Brailsford Vaughns, Anne O'Hara, Loretta s. Novotny, and Theodora Jo Kyle. 'Art Play: Stories of Engaging Families, Inspiring Learning, and Exploring Emotion',” J. YC: Young Children., vol. 69 Issue (2010). 
[6] Asu Besgen, Nilgun Kuloglu, Sara Fathalizadehalemdari. 'Teaching/Learning Strategies Through Art: Art and Basic Design Education,' J. Procedia - Social and Behavioral Sciences, vol. 182 (2015).

[7] Behrens, Katie. 'Craft Work,' School Library Journal, vol. 61 Issue 5 (2015).

[8] Brophy and Kate. 'Cut and Paste,' J. Csholastic Parent \& Child., vol. 13 Issue 4. 2p.1 Color Photograph (2006).

[9] Reeta Sonawat and Purvi Gorgi. 'Multiple Intelligences for Preschool Children,' J. Mumbai: Multitech Publishing C (2008).

[10] Yaumi M. 'Pembelajaran Berbasis Kecerdasan Jamak,' Kencana, p. 27, (2013).

[11] Brent Wilson. 'Reflection on the Relationships Among Art, Life, and Research,' J. Studies in art Education (2015). Charles M Reigeluth, Alexander Romiszowsky, 2009. 'Instructional Design Theories and Models,' Taylor and Francis, vol. III.

[12] Kaufman, Plucker and Rusell. 'Identifying and Assessing Creativity as A Component of Gifttendness,' J. SAGE (2014).

[13] Amir Reza Karimi Azeri, Reza Parvizi, S Jalal Khaleghi, S. Baher Hosseini. EEffective Design Principle in Promotion of Children's Creativity in Residential Spaces,' J. Procedia - Social and behavioral Sciences, vol. 202 (2015) .

[14] Kelly Johnson. 'Creative Connecting: Early Childhood Nature Journaling Spark Wonder and Develops Ecological Literacy,' International Journal of Early Childhood Environmental Education (2014).

[15] R. Torraco, 'Experential Learning Model,' Fo.undation of HRD, http://tc.uni.edu/edad/ torraco/hrd/pdf/session4/Torraco.pdf (2017).

[16] International Montessori Schools and Child Development Centres. 'Naturalistic Intelligence' (2010).

[17] Meyer, Maggie.'Learning and Teaching Through the Naturalist Intelligence,' J. ERIC Clearing n102 (1998).

[18] Morris, William. 'The American Heritage Dictionary of the English Language,' Houghton Mifftin (1976).

[19] A J Romiszowski.'Designing Instructional Systems, Decision making in course planing and Curriculum design.' RoutledgeeFalmer (2016).

[20] Nilgun Kuloglu, Ali O. Asasoglu. 'Indirect Expression as an Approach to Improving Creativity in Design Education,' Procedia-Social and Behavioral Sciences, vol. 9 (2010).

[21] Ajda Senol.'Is Art Mimesis or Cration?', J. Procedia Social and Behavioral Sciences 116 (2014).

[22] Sharon K. McDonough. 'Way Beyond Drill and Practice: Foreign Language Lab Activities in Suport of Constructivist Learning,' Int'l J. of Intructional Media, vol. 28, Iss 1 (2001).

[23] J. W. Budd, "Mind Maps as Classroom Exercises," J. Econ. Educ., vol. 35, no. 1, pp. 35-49, 2004.

[24] Djamarah \& AswanZain. 'Strategi Belajar Mengajar,' Rieneka Cipta (2006).

[25] E Siregar \& Nara.'Teori Belajar dan Pembelajaran,' Ghalia Indonesia (2010).

[26] Regina Yando, Victoria Seitz. Edwar Zigler, 'IMITATION a Development Perfective,' Lawrence Erlbaum Associates Publishers Hillsdale (1978).

[27] Pamela Burnard, Mandy Swann. 'Pupil Perception of Learning with Artists: A new order of Experience?,' Thinking Skills and Creativity, vol. 5, Issue 2 (2010). 